\title{
Dramatising Intelligence History on the BBC: The Camp 020 Affair
}

While there is a considerable literature that considers post-1945 British intelligence historiography, little attention has been given to non-print media, such as factual depictions of intelligence affairs broadcast on television or radio. Using previously closed material from the British Broadcasting Corporation's written archives, this article explores how factual intelligence and security issues were represented by the BBC as the 1970s drew to a close, through an examination of the Spy! television series, which approached episodes of recent intelligence history in a drama-documentary format. The second episode of the series, seen by millions of viewers, proved controversial owing to its depiction of a physical assault during interrogation at an MI5 facility, Camp 020, during the Second World War. The article explores the fallout from this episode, as numerous Camp 020 veterans made great efforts to point out that such physical violence had never taken place. For the most part, this struggle was played out in private correspondence with the BBC, while the general public was left with little reason to question what had been shown, thereby allowing the association of wartime British intelligence with physical abuse to go unchallenged.

While a well-developed body of literature exists that considers post-1945 British intelligence historiography, little attention has been given to coverage of factual intelligence and security issues by non-print media, such as television or radio. ${ }^{1}$ Broadcast non-fiction programmes offered a form of coverage akin to a non-fiction written publication, the most significant difference being perhaps the reach that could be achieved in terms of audience, with millions of viewers potentially tuning in. Such programmes therefore warrant critical attention on account of the influence they could exert, in terms of informing the general public. Through 
previously closed archival material held at the BBC Written Archives Centre, ${ }^{2}$ this article considers an episode of the Spy! television series, which approached episodes of recent intelligence history through dramatic reconstruction; a drama-documentary, or docudrama. Its depiction of the activities of Camp 020, an MI5 facility for captured German spies, included physical violence during an interrogation, which was subsequently fiercely contested by former members of staff from the establishment. For the most part, this struggle was played out in private correspondence with the BBC, while the general public was left with little reason to question what had been shown, thereby allowing the association of wartime British intelligence interrogations with physical abuse to go unchallenged.

Captured enemy agents had potential value for the British intelligence and security committee during the war as double agents, their messages to Germany suggesting that they were still at liberty, while in fact their communications were under British control. In order to 'break' a newly captured spy during interrogation, MI5's officers stationed at Camp 020 were prepared to exert psychological pressure, such as the threat of execution should they refuse to cooperate, and would be willing to acknowledge that such pressure was used years later. However, the use of any form of physical abuse was strictly forbidden. The 'first and unbreakable’ rule of the Camp’s Commandant, Lieutenant-Colonel R.W.G. ('Tin Eye’) Stephens, was 'that physical violence was not to be used under any circumstance'. ${ }^{3}$ The reasoning that lay behind this rule, as Stephens himself explained after the war, was ultimately pragmatic; violence was felt to produce 'answers to please', and generally lowered the 'standard of information' obtained. ${ }^{4}$ The sole exception to this rule concerned the case of TATE, Wulf Schmidt, who was physically assaulted by a visiting interrogator, Colonel A.P. Scotland, of the London District Cage, a separate facility in Kensington run by the Prisoner of War Interrogation Service (PWIS), where Axis POWs were interrogated prior to their transfer to a POW camp. While the extent to which the Cage exceeded the bounds of 
legitimate interrogation techniques has been discussed elsewhere, ${ }^{5}$ the fact that such behaviour was not tolerated at Camp 020 was demonstrated by the fact that, following the incident, Scotland was refused re-entry to the facility, and the use of external interrogators was subsequently forbidden. ${ }^{6}$

Official information detailing the rules under which Camp 020 operated did not enter the public domain until the late 1990s. In common with most other aspects of the wartime British intelligence and security community, the authorities maintained a blanket silence about the activities of Camp 020 for several decades after the end of the war. Volume Four of the official history British Intelligence in the Second World War, which dealt with matters of security and counter-intelligence, made some reference to its work when it was eventually published in 1989, but was hardly extensive in its coverage. Official records relating to Camp 020 were included in the third tranche of files released by the Security Service into the public domain in September 1999 and the following year the internal history of the camp, written by Stephens himself, was released in book form by the Public Record Office. ${ }^{7}$ This did not mean, however, that the general public was wholly unaware of the existence of the wartime facility until the turn of the century. By the time the official record was released, references to the Camp had long been available in the memoirs of German agents who had been held there: 'Many who had experienced the sharp end of the regime told hair-raising stories about executions at midnight and dummy firing squads, the latter apparently designed to give the prisoner one final opportunity “to save himself”, ${ }^{8}$ Circumstantial support for such claims was provided by what was known of Stephens' subsequent career, which had seen him charged with the abuse of prisoners under his control as head of a different facility at the end of the war, irrespective of the fact that all charges had been subsequently dropped. ${ }^{9}$ In short, by the time the official history stated categorically that 'Violence was never used, either at 
the first interrogation or later', Camp 020 had already 'acquired a very sinister reputation', ${ }^{10}$ one which persists in more recent publications about its work. ${ }^{11}$

Alongside the literature which provided the unofficial history of Camp 020 came a BBC television series that brought it to the attention of an audience of millions. The Spy! series, developed and produced in the late 1970s and subsequently broadcast on BBC1 over six weeks in early 1980, coincided with a surge of public interest about intelligence affairs, in both fact and fiction. 'The time could not have been riper for Spy!', wrote Peter Fiddick in the Guardian, while the reviewer for the Financial Times considered the series 'providentially well timed'. ${ }^{12}$ In the autumn of 1979, audiences had been gripped by the BBC’s adaptation of John le Carré's spy thriller Tinker Tailor Soldier Spy. The first episode was broadcast on BBC2 on 10 September, and viewing figures, no doubt given a boost by a strike that took ITV off the air, were high; some eight and a half million viewers tuned in, along with a further three million watching the weekly repeats which served as a refresher for baffled viewers the night before the latest episode. ${ }^{13}$ Hot on the heels of this fictional search for a Russian 'mole' came news of a real one; the public revelation that Anthony Blunt, Keeper of the Queen's Pictures, had some decades earlier confessed to being the 'Fourth Man’ in the Cambridge Spy Ring.

The brainchild of 'old Z Cars hand' Allan Prior, who 'spent three years dusting down volumes in the British Library finding out what he could about the victors and victims of espionage, before narrowing it down to six subjects', ${ }^{14}$ Spy! proved popular with the viewing public. The first episode, broadcast at 9.35pm on Sunday 13 January 1980, was watched by an estimated audience of 4 million, equating to some $7.6 \%$ of the entire UK viewing population, growing to 7.5 million (14.3\%) by its final episode. ${ }^{15}$ According to the BBC’s Audience Research Report, ${ }^{16}$ the first episode was also well received; its 'Reaction Index ${ }^{17}$ was 76, which was considered 'an encouraging start to the series'. ${ }^{18}$ The final episode of the 
series, which told the story of Cynthia, 'a spy on the French Embassy of the Vichy Government in Washington', gained a Reaction Index of 74, the Audience Research report noting that the episode 'was considered all the more interesting because it actually happened ('the tangled web of international aspionage [sic] is even more thrilling when you realise it's not all written by John le Carré')', while more generally 'the bulk of the sample thought true spy stories an excellent theme for a television series'. ${ }^{19}$ Spy! also represented a particular approach to history on television. Consisting of 'dramatised reconstructions of espionage stories', it was an example of drama-documentary, an approach which the programme's Executive Producer, Anthony ('Tony') Isaacs, was instrumental in developing at the BBC. ${ }^{20}$

As well as proving popular with viewers, the series quickly attracted controversy. The first episode, 'John Vassall’, which dramatized the Vassall affair, drew complaints from two of those who had been in Moscow at the time and who were represented in the programme; Lady Hayter, wife of the British Ambassador in Moscow, and Captain Geoffrey Bennett, the Naval Attaché at the Embassy, neither of whom had been notified that the programme was being developed, finding out about it a matter of days before it was broadcast. The BBC was swiftly forced to apologise to both Lady Hayter and Bennett 'for not consulting them before portraying them'. ${ }^{21}$ Even greater controversy followed the broadcast of the second episode, which dramatized the work of Camp 020. The programme began with a voiceover which informed viewers:

On the night of the third of September 1940, a year to the day after hostilities began, a German spy, who called himself Hans Hansen, landed somewhere between Oxford and London by parachute. This is a reconstruction of what happened to him, and to many of the German spies who entered Britain by one means or another during the war. Some were fortunate and survived. Others simply disappeared. Most of them passed through Camp 020. 
Broadcast on 20 January against Roger Moore's James Bond in Live and Let Die on ITV, a juxtaposition of fact and fiction that was not lost on reviewers, the controversy centred around the manner in which Hansen’s interrogation was portrayed. ${ }^{22}$ The viewers were told that it was essential to 'break’ a prisoner within 48 hours to avoid suspicion from his German controllers. With no progress having been made by the 40-hour point, the monocle-wearing Commandant - unnamed, but clearly a representation of Stephens - was shown becoming increasingly agitated, demanding 'more pressure'. His frustration with the interrogator increasing ('Listen to them. A pair of bloody schoolboys having a philosophical discussion!'), the Commandant stormed into the Interrogation room, ordering both the interrogator and interpreter to leave. Barking threats of execution at the prisoner, the Commandant grabbed him by the collar, forcing him against the wall. 'I could choke an answer out of you', he snarled, slamming Hansen's head into the wall, causing blood to run from his mouth. In an adjoining room, where the interrogation was being observed, the evicted interrogator was aghast: 'What in God’s name is he doing? He’s going to kill him!' 'Not quite' replied another observer, a Major known only as Charles. During this exchange, slaps and thuds continued to be heard off-screen, as the assault continued. Back in the interrogation room, the prisoner was shown falling to the floor, seemingly unconscious. 'Pick him up!' ordered the Commandant, marching off. Re-entering the room, the interrogator asked the guards how the prisoner was. The guard replied with a smirk: 'He'll be alright, sir. Feeling a bit rough at the moment. Lack of sleep, I expect'. Later, back in the officers' mess, the Major tells the interrogator, 'He was never in any real danger, you know, we're not allowed to kill people here. There was an incident some time ago, very ugly. Not one of our men, a visiting expert, thank goodness, but there was a hell of a row and the Home Secretary came down and made us promise to behave ourselves', clearly a reference to the incident involving A.P. Scotland. The significance of the scene was not lost on the reviewers. In the 
Sunday Telegraph, Philp Purser wrote that 'despite stiff disavowals of the use of torture in Hugh Connor’s script (“My dear chap, we are English”), a little rough stuff was artfully introduced at a crucial moment in the psychological battery. Indeed, with his jack-boots, monocle and brilliantined hair the Commandant of the interrogation centre was played by Gary Raymond as a mirror image of the Gestapo Sturmbannfuhrer in a million lousy war films'. ${ }^{23}$

But was it true? As Jean Seaton points out in her official history of the BBC, the Corporation was considered 'the provider of authoritative information', a sentiment reflected by the Financial Times, Chris Dunkley noting that 'I suspect that many viewers watching next Sunday’s interrogation, with its disorientation techniques, its monocled officer strutting the mess in his jodhpurs, slapping his crop against his riding boots and knocking the prisoners about, will refuse to believe that such a monster ever ran an English counter intelligence centre. Yet we must assume that this reconstruction is broadly accurate (relying on the many well informed survivors to blow the whistle if not). ${ }^{24}$ The scenes provoked a fierce backlash from a number of former Camp 020 staff, who objected strongly to this depiction of physical violence and did indeed try to blow the whistle. Shortly after the programme was broadcast, a group of 10 former Camp 020 secretaries - Kathleen Williams, Aenea Allen (nee McCallum), Eileen Ball, Helen Clegg, Nancy Farquarson, Joyce Hall (nee Bisset), Brenda Mitchell, Margaret Randall (nee Davidson), Margaret Reynolds and Frances Shanks (nee Lepper) - revealed their wartime employment in a letter to the Radio Times in which they voiced their objections to the programme. ${ }^{25}$ As 'erstwhile members of the secretarial staff of Camp 020', the signatories of the letter wished to 'vigorously protest at the portrayal of the Commandant as a violent and ill-mannered bully'. While they readily conceded that Stephens himself was 'of terrifying aspect', they noted that he 'was a skilled interrogator who obtained results without recourse to assault and battery', emphasising that 'the very basis of Camp 020 
procedure was that nobody raised a hand against a prisoner'. They added that a secretary was 'always' present in the interrogation room, 'in order to take a verbatim record'. To the best of their accumulated, and considerable, knowledge, 'only two prisoners suffered physical injury. One was struck by a visiting interrogator; immediately the Commandant knew of it he condemned the action in the strongest possible terms. (This must be the previous incident mentioned in the programme.) The other prisoner was killed when Camp 020 was hit by a German bomb’. ${ }^{26}$ The letter was published in the 9-15 February 1980 issue of the Radio Times, but only in certain regional editions, alongside a reply from the Producer of the series, Frank Cox. Cox offered a robust defence of his programme, explaining that its depiction of the Commandant 'was reached by way of exhaustive research’. This included letters from Dr Harold Dearden, the Camp’s Medical Officer, along with unnamed 020 secretarial staff and former prisoners - Hansen himself, Eddie Chapman ('ZigZag'), John Moe ('Mutt') and Tor Glad ('Jeff'). Cox also drew attention to the 1948 Court Martial at which Stephens had been acquitted of charges of maltreatment of prisoners during his time commanding another interrogation facility at Bad Nenndorf at the end of the war. 'On the basis of our researches,' Cox concluded, 'it would be dishonest of us to suggest that British wartime interrogations of agents were all conducted with the restraint of a peace-time courtroom'. ${ }^{27}$

Cox’s reply served only to inflame the situation. Further 020 veterans now took up the cause, joining the secretaries in writing their own letters of complaint. Writing to the Editor of the Radio Times, the brothers Alan and William Shanks, both former Interrogation Officers at 020, stated that it was 'totally false to suggest that physical violence played any part whatever in the interrogation techniques we used. Scenes in the programme depicting this... were complete nonsense and contrary to every principle upon which our work at 020 was based'. ${ }^{28}$ They hoped that Cox would 'make suitable public amends' for the 'grave injustice' done to Stephens' memory and 'to every man and woman who worked there, since 
had these things really happened we must all have known, and condoned them'. However, receiving nothing beyond a 'stereotyped acknowledgement' to their letter, Alan Shanks proceeded to send copies of the correspondence to the Director General of the BBC, Ian Trethowan, and subsequently to the BBC Complaints Commission, demanding that the BBC 'should take serious note of our protests, that it should re-examine its source material - and its conscience - and that it should acknowledge the grave errors of fact contained in the programme', an acknowledgement that was expected to be 'public and unqualified'. ${ }^{29}$ Shanks’ letter to Trethowan prompted a response from Jonathan Rooper, a Senior Assistant in the BBC Secretariat, who wrote that 'there is nothing we can really add to the reply by Frank Cox in "Radio Times"... we are satisfied that the programme, which was a dramatized version of real events, was properly researched and produced'. ${ }^{30}$ A further complaint was sent to Alasdair Milne, the BBC’s Director of Programmes, by Mrs Patricia Ward-Thomas, who was 'on the staff of the establishment virtually throughout its existence'. ${ }^{31}$ Milne replied on 19 February, repeating Cox's reply as published in the Radio Times in full. He felt that he could 'not do better by way of response', adding: 'It would seem that there is some disagreement about the nature of this aspect of interrogation but I can assure you that the production team concerned was at pains not to sensationalise. Nevertheless, I am sorry it (sic) their efforts have caused you concern.' ${ }^{32}$ Another Camp 020 veteran, F.G. Beith, proceeded to forensically dismantle Cox's response in a 14-page paper sent to the Editor of the Radio Times, the Secretary of the BBC’s Programmes Complaints Commission and Trethowan. Given that he was 'at Camp 020 for some time and served under Colonel Stephens for over three years', Beith believed that he was 'qualified to offer the attached comments and home truths', ${ }^{33}$ pouring barely concealed scorn on the 'exhaustive research' conducted by the programme team, which had failed to prevent Cox from spelling Stephens’ name incorrectly. Beith took issue with, among other things, the value of the letters of the Camp’s medical 
officer, Dr Dearden, offering his own opinion of the psychiatrist's contribution to 020's work: ‘Dr Dearden’s successes among enemy spies of different origins and many tongues, varied nationalities and toughened psyches were pathetically few, his threatened failures many. He was relegated to the practice of simple diagnoses and cures of physical disorders among a rudely healthy military staff...A less thick-skinned man - the interests he claimed included wrestling and boxing - would have resigned and left'. ${ }^{34}$ In terms of Cox's claim to have interviewed staff from 020, who suggested that Stephens 'was violent on occasions' and that his was a tough regime, Beith agreed that it 'was tough'. However, in relation to the 'alleged violence’ described in 'Mr Cox’s arrogantly dismissive apologia’, Beith added: 'if explosive speech is to rank with physical violence in the censorious Mr Cox's catalogue of wrongs, Colonel Stephens was violent on very many occasions.' Assuming that the 'screen Hansen’ was actually TATE, 'about whom much has already been written', Beith conceded that the claim 'that he was struck' at Camp 020 'cannot be denied', but emphasised that the incident had involved a visiting interrogator, reiterating that 'no violence was used by Colonel Stephens or his staff against prisoners at Camp 020'. Beith closed with a swipe at the voiceover that had started the programme: 'incidentally, there was a passing reference to some of the spies who passed through the place having “disappeared”. They didn't. All were officially accounted for. Ask the Home Office'. Complaints about the programme also began to spread beyond the BBC, as the former Head of Camp 020's Secretarial Staff, Miss Helen Clegg, wrote to Downing Street to express her concerns directly to the Prime Minister, Margaret Thatcher. Having outlined the background, Clegg explained, 'What I am concerned about now is that the corporation should not repeat the Camp 020 programme at a later date, or sell it, as part of the series, to an overseas broadcasting company...may I ask you please to bring pressure to bear on the BBC to acknowledge that their portrait of him [Stephens] is entirely false and to prevent them from showing the programme on Camp 020 again'. ${ }^{35}$ 
While the Complaints Commission again distanced itself from the issue, Beith’s letter to Trethowan prompted another reply from Rooper, who noted that the points he had raised were 'being fully investigated', and promised a reply from the Director-General 'as soon as possible’. ${ }^{36}$ On 28 March, Rooper forwarded 'the various papers containing details of complaints about the programme' to Cox, noting that he 'would be grateful for your advice'. ${ }^{37}$ The BBC’s internal inquiries continued into May; in response to letters from Williams and Beith, Rooper explained that a 'full internal investigation is being carried out', but that this had 'been delayed by a casting crisis affecting one of the programmes for which the producer of "Camp 020" is responsible. This means that he was unexpectedly involved in large-scale auditioning and was not able to assist with the investigations in the weeks that this was in progress'. ${ }^{38}$ With the casting crisis at an end, Rooper hoped that the investigation would be completed in 'the next week or so'. In the meantime, Rooper agreed with Cox that he 'would try to draft a reply after watching the videotape'. ${ }^{39}$ Having done so, Rooper sent it to Cox for his comments. From the file material, this viewing appears to have constituted the substantive part of the BBC's internal investigation.

On 19 June Rooper’s draft letter, now signed by Trethowan, was sent to Beith, variants sent to the other complainants. The letter reaffirmed the BBC’s position that the source of information on the violence that had taken place - Hansen himself - was considered reliable: 'so far as the interrogation of Hansen is concerned, our account was based on the evidence of Hansen himself (he is now a successful and respected journalist living in the UK) and I am satisfied that the way the interrogation was presented in the programme was fair and accurate' ${ }^{40}$ The letter also sought to downplay concerns over the violence depicted on screen ('My own reaction to this scene is that what was actually shown was comparatively mild, and could not be termed serious violence'), neglecting to mention 
the horror on the interrogator's face as he watched the assault continue off screen. Trethowan even offered a justification for the assault:

The context of Colonel Stephens' actions is of vital importance: it was made quite clear that his intervention in the Hansen interrogation was on the grounds that not enough progress was being made to allow the critical 48-hour deadline to be met...In short “Camp 020” was a study of a successful counter-espionage measure which was mounted in an entirely proper way.

Trethowan was only willing to concede that such violence, which he considered 'mild', may well have been 'exceptional', and not a regular occurrence. In conclusion, the Director General attempted to placate those who had complained by pointing to the challenges faced when trying to recreate events for television:

There is, of course, always likely to be a feeling on the part of those who were actually involved in events depicted in a television programme that the dramatization has given an inaccurate picture of what took place. In so far as details are concerned, this is bound to be so to some extent and I would not pretend that we could achieve absolute accuracy on all minor points. But this is not essential in order to give an overall impression that is correct...I am satisfied that the way the interrogation was presented in the programme was fair and accurate. ${ }^{41}$

Such a comment about the 'overall impression' given by the programme served to effectively nullify his earlier admission that any violence may have been the exception rather than the rule. As such, Trethowan's letter did little to placate the 020 veterans, while Rooper proceeded to inflame matters further in his response to the latest letters from Kathleen Williams and Aenea Allen, which effectively challenged the veterans' ability to question the offending scene with authority: 
...since no-one who has complained about 'Camp 020' claims to have witnessed the events depicted in the programme, there is no-one in a position to know that Hansen's claim that he was struck by Colonel Stephens is untrue. With the greatest respect, you cannot expect that we should believe that you and your colleagues have disproved Hansen's account on the sole grounds that you never witnessed violence while you were working at the Camp. ${ }^{42}$

Similar comments were made by another BBC official, J.F. Wilkinson, in response to a further letter from Shanks to Trethowan. Wilkinson noted: 'the programme’s account of that part of the interrogation conducted by Colonel Stephens, showing no one else present, was supported by first hand information. If you or any other of your former colleagues were there at the time it is puzzling why, to our knowledge, none of you has yet come forward to say so'. ${ }^{43}$ The observation proved timely. Only once during the broadcast programme had the German agent been referred to by his real name, Wulf Schmidt, codename TATE. Rather, he was referred to by the entirely fictitious name Hans Hansen. As such, the reference was missed by a number of the correspondents, who wrote further once Hansen's true identity had become clear, thanks to the publication of a tie-in book related to the series. ${ }^{44}$ On 27 August, Williams wrote again to Rooper. Now aware that the spy in question was Schmidt, she could challenge the version of events depicted on screen with confidence: 'I was present at the Commandant's interrogation of Wolf Schmidt on his arrival at Camp 020. When Schmidt learned that we had already been informed of his coming and were awaiting him he decided to confess'. She added that she 'remained throughout' the interrogation, and was 'not, as was the secretary in the programme, rudely ordered out by the Commandant', who 'remained seated at the table throughout'. Clearly jubilant, she continued: 'I think you must now accept that the foregoing...disposes of your point that none of us is in a position to know that Hansen's "claim that he was struck by Colonel Stephens is untrue”, ${ }^{45}$ In reply, Rooper 
somewhat begrudgingly conceded that her declaration 'does indeed cast a new light on the matter'. Nevertheless, he proved reluctant to provide the admission Williams sought:

In view of your declaration, the BBC would accept that doubt has been cast on the accuracy of Schmidt's account of his interrogation. I wonder, however, if you can be certain that the interrogation which you attended was the only one which Schmidt was subjected to. Equally, though I have always stressed that our film concerned a particular and exceptional case, we would not have accepted Schmidt's account by itself; we only did so because several other accounts indicated that it was an accurate representation. ${ }^{46}$

Clearly having been informed about Williams' statement, Shanks wrote again to both Wilkinson and Trethowan, noting 'You now have in your possession a declaration from each of the two secretaries involved in the "Hansen” case... "Hansen's" alleged statement that he was hit by Colonel Stephens must surely be seen now, even by you, for what it really is. Either “Hansen” (or Schmidt, call him what you will) has lied and you have believed him or, as I personally suspect, he never said it at all!' ${ }^{47}$ The development appears to have caused some concern within the BBC; Trethowan scribbled across the top of the letter; 'I believe we are on rather shaky ground on this issue.' Yet any such private doubts did not prevent the continued defence of the programme. In reply to Shanks, Wilkinson wrote along similar lines to Rooper, noting that while Williams' letter 'does indeed cast doubt on the information we have received from Hansen':

...we did not rely solely on his information: it was corroborated by the accounts of other former inmates of the Camp, a former member of the Camp’s interrogation staff, and a former secretary at the Camp. Thus, while I accept Miss Williams’ statement, I do not believe there is cause for the BBC to reconsider its view on the programme. 
In closing, he reiterated the BBC's regret at causing distress; 'Our purpose was simply to show an immensely efficient counter-intelligence process in action'. ${ }^{48}$ Shanks considered the reply 'a most extraordinary letter...I can hardly believe that it is meant as a serious contribution' ${ }^{49}$

To the incredulity of the 020 veterans, the BBC continued to defend the programme, and its own interpretation of the history of Camp 020. In reply to a further letter from Williams, Rooper noted that 'Schmidt has claimed to us that he was struck by Colonel Stephens, and so have other former inmates of the Camp. We have also received corroboration of these incidents from former members of the Camp's staff', reiterating that the $\mathrm{BBC}$ 'made the programme in good faith and, having done my best to review impartially all the information and everything that you and others have written about it, I cannot accept that we have done a grave injustice to anybody or that the impression left by the programme is as you suggest. ${ }^{50}$ Shanks, meanwhile, continued to press the four points from his earlier letter, asking for further details of what the former prisoners had said, and for a copy of the letter written by Dearden. ${ }^{51}$ This was too much for the DG. On top of Shanks' letter, Trethowan scribbled 'I think the time has come to say “No”. We can’t reveal our informants. The programme had a relatively small audience, and was broadcast nearly a year ago. I agree this most tiresome affair should come to an end', a sentiment conveyed in the letter ultimately sent, which also emphasised that 'the incidents depicted in the Camp 020 programme were carefully corroborated in each case'. ${ }^{52}$ Writing to Williams on 24 November, Rooper similarly noted that 'I can assure you that nothing was included in the "Spy" programme on "Camp 020” that was not corroborated by at least two separate sources. ${ }^{53}$ Shanks continued to press further for the BBC to reveal its sources, to no avail. ${ }^{54}$ On the basis of the BBC's refusal, Shanks was prepared to let the matter drop, concluding that 'your insistence upon a 
spurious plea of confidentiality is an open admission that the "supporting evidence" of certain named individuals will not bear scrutiny'. ${ }^{55}$

The affair dragged on into 1981. Unhappy with the BBC’s treatment of their complaints, the former members of 020 who had continued their correspondence - Clegg, Williams, Allen, Mr and Mrs Shanks and Beith - together took their complaint to the Broadcasting Complaints Commission. ${ }^{56}$ Their efforts were in vain; on 10 July, the Secretary to the BCC replied that the body, only set up in June 1981, had 'no authority to consider programmes broadcast before 1st June 1981'. ${ }^{57}$ The papers were instead passed on to the $\mathrm{BBC}$, where there was no enthusiasm for further discussion. ${ }^{58}$ Further support for the veterans' cause was now forthcoming from T.A. ('Tar') Robertson, the wartime MI5 officer who had been responsible for running double-cross agents as Head of its B1A section, and who had worked closely with Schmidt. On 8 July 1981 Robertson wrote to Clegg, noting that he had watched the programme and had been 'horrified at its inaccuracy':

The agent depicted in the film was, in fact, one of my best agents...I am still in touch with him, as he lives in this country and he comes to see me from time to time. After the appearance of the film he rang me up in a frenzy and declared that it was the most despicable piece of nonsense he had ever seen, and said over and over that he had received fair treatment from all at 020 and that he had never once had a finger laid on him by anyone, and the part which shows him beaten up by Stephens was disgraceful. ${ }^{59}$

Given that Schmidt had been assaulted by Scotland while at 020, an incident that was already acknowledged by the complainants, his claim never to have 'had a finger laid on him by anyone' is surprising. Nevertheless, Clegg was quick to inform the Complaints Commission of the development, ${ }^{60}$ while Shanks notified Trethowan, pointing out that 'It must be plain therefore that in claiming that this scene is based upon the evidence of "Hansen” himself, you 
have been quite shamefully misinformed by those responsible for the programme, and so misled into taking the stance you have over this affair’ ${ }^{61}$

The BBC, then, found itself increasingly backed into a corner. The secretaries present at Schmidt's interrogations were prepared to state that no physical assault had taken place, while Schmidt himself also denied any such treatment. The BBC’s response was to stonewall, as problems with the depiction of events given by the programme were now revealed internally. In a memo dated 17 September, Rooper gave the fullest explanation of the circumstances surrounding the programme that was committed to paper, and which warrants quoting at length:

The Camp 020 lobby has been a very well organised and persistent one. They have attacked the programme we broadcast in January $1980 \ldots$ on the grounds that it misrepresented the commandant of the Camp, Colonel Stephens. In fact, the production team had access to information and corroborating evidence which showed that the portrayal of Colonel Stephens was by no means unfair - indeed, that it was a pale shadow of the truth. In any event, the 'violence' which Colonel Stephens was shown to use in the programme was mild by the standards of television; he merely slapped a spy under interrogation round the face.

Our achilles heel is that the story told in the programme was a composite of the experiences of two spies who were interrogated at the Camp. The scriptwriter was aware of this, but the producer did not learn about it until after the first few exchanges between us and Camp 020 staff. By that stage we had leaned fairly heavily on the information we had received from [Schmidt] and had acknowledged his identity. It is of course this spy whom Mr Shanks refers to in his letter as denying that he was ever 
treated at all roughly by Colonel Stephens; it was the other spy who was treated in the way shown in the programme (though he was by no means the only one to suffer the experience).

I think we should stick to our guns because there is a good chance the lobby will go away if we do. There is a slight risk that we may be embarrassed by external pressure from MPs etc if the lobby continue to press their case, but it seems to me it would be more damaging to admit that we had used composite characters in a dramatized reconstruction without making this clear on the air and without acknowledging the fact during several exchanges of letters. ${ }^{62}$

At the bottom of the letter, a scribbled note added: 'not a happy situation. The trouble is that if we do not admit the error the [sic] Shanks and others will be convinced that we are lying. But if at this stage we do admit it!' The BBC followed Rooper’s advice, and continued to weather what remained of the storm, suggesting in further correspondence that 'it is now time to let the matter drop' ${ }^{63}$ Immovable in its defence of the programme, the correspondents came to realise that there was little point in pursuing the matter further. Kathleen Williams made one further effort at a formal complaint, this time to the Chairman of BBC Governors, George Howard. ${ }^{64}$ An internal minute which followed drew attention to Rooper's earlier correspondence, noting; 'You will see the reasons set out there why we decided to stick to our guns and presumably we shall continue to do so' ${ }^{65}$

Rooper's memo represents the only written admission amongst the official paperwork that there were problems with its depiction of Schmidt's time at Camp 020, yet it remains less than satisfactory, relying quite heavily on suggestion and innuendo in the place of full disclosure. Did the BBC actually have incontrovertible evidence of physical abuse being carried out at Camp 020? What exactly was it that made the depiction of Stephens a 'pale 
shadow of the truth'? Who were the other spies who suffered the same experience as that depicted in the programme? And perhaps most importantly, if the programme had indeed been a 'composite' of the experiences of two spies held at 020, and the experience of violence had not come from Schmidt, then what was the identity of the other spy? In this reverse whodunnit, the initial response from Cox, published in the Radio Times, provides us with a shortlist of potential victims, naming three further spies who had been consulted by the production team, and who 'gave us detailed accounts of their experience at the hands of Colonel Stevens' [sic]: Eddie Chapman, John Moe ('Mutt') and Tor Glad ('Jeff'). Did any of these men experience ill treatment at Scotland's hands, or those of his officers, during interrogation? There is no evidence in the public domain which supports such a suggestion. Nigel West, who had been involved with the research for both the programme and the book, would later write in his own history of MI5 that Chapman 'was so angry about being locked up and treated as a spy that he threatened not to co-operate unless he was released immediately', while Moe 'was merely irritated by the attitude of his captors. He too protested about Stephens' accusations and spent only a minimum time at 020 ' ${ }^{66}$ As Hoare notes, both Moe and Glad together spent 'no more than 24 hours' at $020 .{ }^{67}$ Cox's original letter also made reference to interviews with staff about Stephens, 'who told us that his was a tough regime and that he was violent on occasions'. Was this actually a reference to physical violence? No one denied that Stephens had ‘a fearsome reputation as a temperamental authoritarian' with a short fuse, but it has also been suggested that 'his intimidating manner and appearance were largely an act for interrogation purposes' ${ }^{68}$ Ultimately then, the narrative denouement of the '020 affair' as told by the file material remains problematic; perhaps the most that can be said is that while the possibility of further incidents of assault cannot be entirely ruled out, there is little material which gives substantive support to such claims. 
This would not be the first, or last, time that a broadcast drama-documentary would prove controversial; as Kilborn notes, 'Of all the television formats which have over the years secured a place for themselves in the broadcasting schedules the docudrama... is the one which has possibly occasioned the most lively, and at times the most heated, debate' ${ }^{69}$ Some consider the form too tempting for broadcasters 'to indulge in an irresponsible "monkeying around with actuality"', something the Shanks brothers believed had occurred in the cases of the 020 episode, drawing a distinction between artistic license, which they considered 'permissible if a dull and otherwise uninspiring item is thereby transformed into good television', and 'gross distortion of fact'. ${ }^{70}$ Even if history had been rewritten for public consumption, did it matter? Certainly to the veterans themselves, who clearly felt that their personal integrity had been slighted. In a letter to Trethowan, Shanks observed that 'Viewers could quite readily assume from this scene that this was permissible practice at the camp, that other interrogators also indulged in it, and that it was generally condoned. I find this a reflection upon my wife, who is a former secretary at the camp, upon myself as a former interrogating officer, and upon the memory of my late brother who was also for a time an officer at Camp 020'. ${ }^{71}$ In expressing such concerns over what the public would now believe, Shanks reflected a more general criticism of the docudrama format: 'In the case of audience response to DDs, one of the most frequently made assumptions is that audiences will simply not be in a position to separate fictional from factual. They are...in danger of being seriously misled, since the factually based material has invisibly merged with various types of fictional elaboration and this amalgam created its own reality'. ${ }^{72}$ But is this actually the case? Would viewers have readily assumed the worst, as Shanks feared? Some are sceptical over the powers ascribed to docudrama, suggesting that 'The claim that DDs have a decisive effect on the way that audiences construct their conception or social and political reality has been "asserted far more often than it has been tested", ${ }^{73}$ A US study, conducted within a few years 
of the broadcast of the Spy! series, put that assertion to the test, exploring the prevailing orthodoxy that the documentary drama format 'powerfully influences viewers' conceptions of social and political reality'. ${ }^{74}$ Its conclusions suggested otherwise; while acknowledging that there was the possibility that a degree of influence could be exerted, the format ultimately lacked the power to 'hypnotise' its audience; rather, the reinforcement of an existing view was altogether more likely than 'conversion'. ${ }^{75}$ What existing knowledge would the general public, as opposed to the interested observer, have had upon which to base its view of the British intelligence community in 1980? Likely little of substance, owing to the dearth of reliable information in the public domain about its work at this point; SIS, the Security Service and GCHQ were not yet avowed, while the Waldegrave, or Open Government, Initiative, which would see thousands of previously secret documents released into the public domain, was over a decade away, the release of MI5's own historical papers even further. However, altogether more prominent in the public domain were allegations about ill treatment during interrogation by UK security authorities in the relation to the ongoing Troubles in Northern Ireland. The audience was more likely to have been aware of the fact that interrogation could prove controversial; November 1971 had seen the UK prosecuted by the Republic of Ireland for the use of the 'five techniques ${ }^{76}$ during interrogation of 14 men interned in Northern Ireland, while in January 1976 the Commission of Human Rights concluded that these techniques constituted torture 'when used in combination'. ${ }^{77}$ Would the audience have been particularly surprised by a physical assault during wartime interrogation when the UK had admitted to the use of such methods during peacetime? Indeed, beyond application of such techniques, the possibility of physical assault during interrogation was raised in March 1979, less than a year before Spy! aired, when the Bennett Report into police interrogation procedures in Northern Ireland drew attention to a number of instances where injuries, which were not self-inflicted, were 'sustained during detention'. ${ }^{78}$ Would such near 
contemporary affairs stories have served to reinforce the wartime interrogation as depicted on screen? At almost 40 years remove it is, of course, impossible to answer this question. It is, however, possible to discern the shadow of contemporary interrogation in some of the correspondence between the 020 veterans and the BBC. In one of his letters to Beith in which he defended the approach to interrogation depicted on screen, Trethowan argued that 'Systems of this kind are perfectly justifiable in peacetime police work; who could doubt that in the midst of the Second World War they were essential? ${ }^{79}$

One area where a little more can be said in terms of consequences concerns the reaction among Whitehall civil servants. The Spy! series in general, and the 020 episode in particular, was used by government officials, somewhat counterintuitively, to argue in favour of continued secrecy surrounding wartime intelligence and security activity. In early 1980, the question of whether the final two volumes of the Official History, British Intelligence in the Second World War, should be published was under discussion. While publication of the first three volumes had been approved by Jim Callaghan, his successor as Prime Minister, Margaret Thatcher, was far less supportive of the project. In a note for Sir Robert Armstrong, the Cabinet Secretary, H.L. Theobald of the Cabinet Office Historical Section drew attention to the 'avid public interest in clandestine operations in peace and war':

There has been little pause since the History was first commissioned in the appearance of books and articles, TV and radio presentations about all aspects of intelligence activity; and recently the flow has, if anything, increased. ${ }^{80}$

Theobald's observation marks one of the earliest official discussions of unofficial coverage of intelligence matters that broadens its definition to include works broadcast on television or radio, viewing these with the same measure of concern as written publications. ${ }^{81}$ That Theobald had the series in mind is clearly illustrated by a further minute in which he pointed 
to an article in the Sunday Telegraph concerning double agent work, which he considered 'symptomatic of the private publications which are now emerging, and which appear destined to be reflected in the current BBC1 TV series "Spy!". ${ }^{82}$ Further attention was drawn to the programme in an analysis of manuscript of Volume Four of the official history prepared by Sir Robert's Private Secretary, D.J. Wright, who noted that publication 'could provide a rich source of material for journalists, academics and television'. Under the sub-heading of 'Media Treatment', he pointed to the specific cases of the double cross agents GARBO, SNOW and ZIGZAG, noting that 'there is a hard-core who worked for British intelligence throughout the whole war and whose cases could certainly provide a basis for a successful media treatment. The recent BBC series "Spy”, which contained individual dramatisations of spy cases, seems to be the sort of programme which could benefit from the publication of this material. ${ }^{, 83}$ The point was incorporated into Sir Robert’s submission to the Prime Minister on the question of publication:

The recent BBC “Spy” series of dramatisations of individual spy cases seems to be the sort of programme which could benefit from the publication of this material. One of the programmes in January, I believe, dealt with Camp 020, an interrogation centre for suspected enemy agents which is frequently mentioned in the History...Although the detailed description of the work of Camp 020 has been omitted in the sanitisation, the activities (sometimes understandably rather grisly) of an interrogation centre are likely to remain of real interest to journalists and the object of further investigative “digging”. 84

Such observations were hardly likely to assuage the Prime Minister's concerns, with Thatcher ultimately concluding that neither of the remaining volumes should be published. ${ }^{85}$ Informing a colleague at the Ministry of Defence of the decision not to publish, Sir Robert explained that the concern that such a move would 'fuel rather than damp down the flame of current 
Press interest in and curiosity about all intelligence and security matters...Neither volume is therefore to be published and they are both being put into cold storage until it is thought appropriate to consider once again the possibility of publishing them' ${ }^{86}$ Ill-informed coverage of intelligence matters remained preferable to more accurate accounts as far as the authorities were concerned, at least for the time being.

Some 18 years on from the broadcast of the Spy! series, by which point the Security Service had started to release its historical papers into the public domain, among them Schmidt's MI5 case file, the BBC broadcast another documentary about MI5 activity during the Second World War. ${ }^{87}$ Benefitting from access to this recently-released file, the programme - which included an on-screen interview with Alan and Frances Shanks, fierce critics of the earlier programme - offered an altogether less dramatic reconstruction of Schmidt's interrogation, as a camera showed an empty interrogation room while a voiceover read extracts from the transcript of the interrogation, with not so much as a hint of a physical assault taking place. While Stephens continued to be characterised as terrifying, this time no suggestion of physical violence at the facility was made; Hugh Astor stated that he was 'absolutely certain that there was never any form of physical torture used' (adding 'a degree possibly of mental anxiety'). The earlier programme represents, perhaps, the 'received wisdom’ described by John Ferris when discussing the history of another Second World War institution, Bletchley Park, back in 2000: 'Our knowledge is received wisdom: what we have been told, not what we have learned. Much remains to be found and some to be forgotten' ${ }^{88}$ At a time when the availability of accurate, reliable information about the workings of British intelligence was limited, coupled with the reputation of the BBC as a source of reliable information and recent events in Northern Ireland, it can be suggested, at least, that the general audience would likely have accepted what they had been told, even if they thought little more about it as they got on with their everyday lives. The association of wartime 
intelligence interrogation with physical abuse was allowed to stand, effectively unchallenged, in the public arena. While the efforts of the veterans to correct the impression given by the programme certainly deserve to be remembered, its depiction of a physical assault on a prisoner by the Commandant should now, perhaps, be forgotten.

\section{Bibliography}

\section{Primary Sources}

British Broadcasting Corporation, Written Archives Centre, Caversham, R78/1233/1, 'Spy!' British Broadcasting Corporation, Written Archives Centre, Caversham, Audience Research Report: Spy! 1: John Vassall, February 13, 1980.

British Broadcasting Corporation, Written Archives Centre, Caversham, Audience Research Report: Spy! 6: Cynthia, April 2, 1980.

Radio Times, January 13, 1980, https://genome.ch.bbc.co.uk/schedules/bbcone/london/1980$\underline{01-13}$

The National Archives of the UK (TNA), Records of the Cabinet Office (CAB), 103/742, Official History of British Intelligence in the Second World War: Volume 5, Strategic Deception; 103/743, Official History of British Intelligence in the Second World War: volume 4, Security and Counter-Intelligence.

\section{Secondary Sources}

Adams, William C., Salzman, Allison; Vantine, William; Suelter, Leslie; Anne, Baker; Bonvouloir, Lucille; Brenner, Barbara; Ely, Margaret; Feldman, Jean and Ziegel, Ron. 'The 
power of The Right Stuff: A Quasi-Experimental Field Test of the Docudrama Hypothesis', Public Opinion Quarterly 49, no. 3 (1985): 330-339.

Aldrich, Richard J. 'Policing the Past: Official History, Secrecy and British Intelligence since 1945’, English Historical Review 119, no.483 (2004): 922-953.

Anon. 1980. ‘The Spy Who Struck Lucky’, Evening News, January 11 (np).

Anon. 1980. ‘Did You See?’, Evening News, January 14 (np).

Anon. 1999. 'Obituary: Tony Isaacs’. The Independent, September 9

https://www.independent.co.uk/arts-entertainment/obituary-tony-isaacs-1117321.html

Cobain, Ian. Cruel Britannia: A Secret History of Torture (London: Portobello, 2013).

Conyers, Tony. 1979. 'Closed-Circuit TV Watch Urged on Interrogations', Daily Telegraph, March 17: 8.

Craig, Malcolm M. 'Spycatcher's little sister: the Thatcher government and the Panorama affair', Intelligence and National Security 32, no.6 (2017): 677-692.

Day-Lewis, Sean. 1980. ‘Spy Film Complaint Upheld’, Daily Telegraph, August 7: 16.

Deacon, Richard with West, Nigel. Spy! London: BBC, 1980.

Dunkley, Chris. 1980. 'Silent movies and the secret service’ Financial Times, January 16: 15.

Ferris, John. 'The Road to Bletchley Park: The British Experience with Signals Intelligence, 1892-1945’, Intelligence and National Security 17, no.1 (2002): 53-84.

Fiddick, Peter. 1980. 'Television’, The Guardian, February 4 (np).

Hoare, Oliver (Intro.) Camp 020: MI5 and the Nazi Spies. London: Public Record Office, 2000. 
Kavanagh, Jacqueline. ‘The BBC’s Written Archives as a Source for Media History’, Media History 5, no.1 (1999): 81-86.

Kilborn, Richard. ““Drama over Lockerbie” A new look at television drama-documentaries’, Historical Journal of Film, Radio and Television 14, no.1 (1994): 59-76.

Lomas, Daniel W.B. 'A Tale of Torture? Alexander Scotland, The London Cage and postwar British secrecy', in Intelligence Studies in Britain and the US, edited by Christopher R. Moran and Christopher J. Murphy. Edinburgh: EUP, 2013.

Moran, Christopher. Classified. Cambridge: CUP, 2012.

Murray, James. 1980. ‘A Spy Who Puts Bond to Shame’, Daily Express, January 19 (np).

Newbery, Samantha L. 'Intelligence and controversial British interrogation techniques: the Northern Ireland case, 1971-2', Irish Studies in International Affairs 20 (2009): 103-119.

Purser, Philip. 1980. ‘Television’, Sunday Telegraph, January 27: 13.

Seaton, Jean. 'Pinkoes and Traitors': The BBC and the nation, 1974-1987. London: Profile, 2015.

Sisman, Adam. John le Carré: The Biography. London: Bloomsbury, 2015.

Smart, Billy. 'The BBC Television Audience Research reports', Historical Journal of Film, Radio and Television 34, no.3 (2014): 452-462.

Spy! Camp 020. Directed by John Bird. Originally broadcast on BBC1, January 20, 1980.

Stringer, Robin. 1980. 'Vassall Apology by BBC’, Daily Telegraph, January 15: 3.

Timewatch: The Spies Who Fooled Hitler. Directed by Tilman Remme. Originally broadcast on BBC2, November 18, 1997.

West, Nigel. MI5 (London: Triad Grafton, 1983). 
Wyllie, James. 'BBC Archives Caversham: an unlikely treasure', Soccer \& Society 21, no.1 (2011): 9-10.

${ }^{1}$ For intelligence historiography see Moran, Classified; Moran and Murphy (eds.), Intelligence Studies; Aldrich, 'Policing the Past'. For a rare example of a study that goes beyond printed material, see Craig, 'Spycatcher's little sister'.

${ }^{2}$ For further details of the nature of the material held at the archive, see Kavanagh, 'The BBC’s Written Archives'. For a more light-hearted first-hand account of a researcher's experience at the Centre, see Wyllie, 'BBC Archives'.

${ }^{3}$ Hoare, Camp 020, 19.

${ }^{4}$ Hoare, Camp 020, 19.

${ }^{5}$ For further details on A.P. Scotland and the work of the London District Cage, see Lomas, 'A Tale of Torture?'

${ }^{6}$ Hoare, Camp 020, 20.

${ }^{7}$ Now The National Archives.

${ }^{8}$ West, MI5, 187.

${ }^{9}$ Hoare, Camp 020, 7-8.

${ }^{10}$ West, MI5, 187.

${ }^{11}$ Ian Cobain, for example, has recently argued that 'The claim that violence was taboo at Camp 020 was a lie’. (Cobain, Cruel Britannia, 75.)

12 Fiddick, ‘Television', March 2, 1980; Anon, The Guardian, February 4, 1980; Anon, Financial Times, January 16, 1980. According to the Evening News, the series was ‘fortuitously timed’ (Anon, 'Did You See?', January 14, 1980, np.) It was noted elsewhere by the paper that 'The timing and scheduling of TV programmes is a chancy business...But with 
Spy!...the schedulers' luck was in. The six-part series was planned and made months before Anthony Blunt et al put espionage back on the front pages’ (Anon, 'The Spy Who Struck Lucky’, January 11, 1980, np).

${ }^{13}$ Sisman, John le Carré, 406.

${ }^{14}$ Anon, ‘The Spy Who Struck Lucky’, January 11, 1980, np.

${ }^{15}$ Radio Times, January 13, 1980; Audience Research Report: Spy! 1: John Vassall, BBC Written Archives Centre (hereafter WAC), February 13, 1980.

16 The BBC's Audience Research Unit compiled reports on several hundred programmes per year. As Smart explains, these reports are valuable as they help us 'to understand what people thought about a range of television at the time that it was broadcast, rather than retrospectively...the great value of the Audience Research reports lies in their record of everyday responses, which would otherwise have been quickly forgotten and lost forever'. (Smart, 'The BBC Television Audience Research Reports', 454-5.)

${ }^{17}$ In addition to providing details of when the programme was broadcast and 'an estimate of the audience size in terms of percentage of the UK population', efforts were also made 'to gauge audience reception (the Reaction Index) through a mark out of 100 compiled by asking viewers to rate the programme seen on a five point scale'. (Smart, 'The BBC Television Audience Research Reports’, 453.)

${ }^{18}$ Audience Research Report: Spy! 1: John Vassall, WAC, February 13, 1980. The first episode was also favourably received by the Evening News reviewer, who wrote that 'The presence of the exclamation mark...suggested that the stories were going to be racy, lurid and sensational', but noted that 'this series, devised a couple of years before our appetite for espionage was Blunted, takes a refreshingly unsensational approach to the whole dirty business’. (Anon, ‘Did You See?’, np.)

${ }^{19}$ Audience Research Report: Spy! 6: Cynthia, WAC, April 2, 1980. 
${ }^{20}$ Radio Times, January 13, 1980, np; Anon, 'Obituary: Tony Isaacs’, np.

${ }^{21}$ Lady Hayter acknowledged that there were mistakes in the programme, but nevertheless thought 'that within its limits' it 'presented a fair portrayal'. (Stringer, 'Vassall Apology', 3.) Bennett had not been consulted as 'he was thought to be dead' - which, he observed, 'did suggest a rather slipshod approach to research’. This resulted in an apology from the producer, Frank Cox, and the director, Ben Rea. Concerned with the impact the programme could have on his reputation ('I was much more on the ball than the programme showed'), Bennett proceeded to make a formal complaint about the programme, with limited success. The BBC Programmes Complaints Commission, which upheld his complaint about the failure of the $\mathrm{BBC}$ 'to identify him as a living person or to notify him that the programme was being made', but 'did not consider the portrayal was unfair to him or reflected adversely on his reputation as a naval historian'. (Stringer, 'Vassall Apology’, 3; Sean Day-Lewis, 'Spy Film Complaint Upheld', 6.)

${ }^{22}$ Murray, 'A Spy Who Puts Bond to Shame’, np. Noting that the programme was up against 'the most famous fictional spy of all time’, Murray added, 'I suspect viewers might do better with the real thing'.

${ }^{23}$ Purser, ‘Television', 13.

${ }^{24}$ Seaton, Pinkoes, 283; Dunkley, 'Silent movies’, 15.

${ }^{25}$ Copies of the letter were also sent to the national press, which saw its publication in the Daily Telegraph on January 30, 1980.

${ }^{26}$ COPY: Radio Times/East Region (9-15 February 1980) Letters Page, WAC, R78/1233/1. ${ }^{27}$ Ibid.

${ }^{28}$ Alan and William Shanks to The Editor, Radio Times, February 16, 1980, WAC, R78/1233/1. 
${ }^{29}$ Shanks to The Commissioner, BBC Programmes Complaints Commission, February 24, 1980, WAC, R78/1233/1.

${ }^{30}$ Rooper to Shanks, February 28, 1980, WAC, R78/1233/1.

${ }^{31}$ Beith to Trethowan, February 14, 1980, WAC, R78/1233/1,

${ }^{32}$ Cited in Beith to Trethowan, February 14, 1980, WAC, R78/1233/1, Beith added:

'Couldn’t he do better, either, for an apology?'

${ }^{33}$ Beith to the Editor, Radio Times, March 14, 1980, WAC, R78/1233/1.

${ }^{34}$ Beith to Trethowan (Copied to The Secretary, BBC Complaints Commission), March 14, 1980, WAC, R78/1233/1.

${ }^{35}$ Clegg to Thatcher, March 11, 1980, WAC, R78/1233/1. It is unclear whether the Prime Minister herself ever saw the letter, which was forwarded to the Home Office. Replying to Mrs Clegg, A.M. Jowitt of the Broadcasting Department explained that it was 'a principle of long standing...that the broadcasting authorities should have editorial responsibility for the content of their programmes', adding 'I am sure you will recognise the undesirability of Government intervention in these matters'. He noted that he would forward the correspondence to the $\mathrm{BBC}$, 'so that they may be aware of your representations to the Prime Minister’. (Jowitt to Clegg, April 28, 1980, WAC, R78/1233/1.)

${ }^{36}$ Stapley to Beth [sic], March 20, 1980, WAC, R78/1233/1. Rooper sent another letter on 10 April, acknowledging receipt of Beith's material that had also been forwarded from the Complaints Commission, again noting that 'your comments are being fully investigated and I shall be replying to you in detail as soon as possible'. (Rooper to Beith, April 10, 1980, WAC, R78/1233/1.)

${ }^{37}$ Rooper to Cox, March 28, 1980, WAC, R78/1233/1.

${ }^{38}$ Rooper to Williams, 13.05.80; Rooper to Beith, 13.05.80. WAC, R78/1233/1.

${ }^{39}$ Rooper, Memo, May 13, 1980, WAC, R78/1233/1. 
40 Trethowan to Beith, June 19, 1980, WAC, R78/1233/1.

${ }^{41}$ Trethowan to Beith, June 19, 1980, WAC, R78/1233/1.

${ }^{42}$ Rooper to Williams, August 5, 1980, WAC, R78/1233/1.

${ }^{43}$ Wilkinson to Shanks, September 1, 1980, WAC, R78/1233/1.

${ }^{44}$ Deacon with West, Spy!

${ }^{45}$ Williams to Rooper, August 27, 1980, WAC, R78/1233/1.

${ }^{46}$ Rooper to Williams, September 3, 1980, WAC, R78/1233/1. Rooper’s question about the possibility of further interrogations was addressed by another secretary, Mrs Ward Thomas; either Williams or Ward Thomas ‘was present at every interrogation’. (Shanks to Trethowan, 4 September 1980, WAC, R78/1233/1.)

${ }^{47}$ Shanks to Trethowan, 4 September 1980; Shanks to Wilkinson, 4 September 1980, WAC, $\mathrm{R} 78 / 1233 / 1$.

${ }^{48}$ Wilkinson to Shanks, September 19, 1980, WAC, R78/1233/1.

${ }^{49}$ Shanks to Trethowan, September 24, 1980, WAC, R78/1233/1. Kathleen Williams was similarly critical of the BBC's continued stance in her reply to Rooper in September, noting: 'You have now heard from the two secretaries one or other of whom was present throughout every interrogation of Schmidt by the Commandant. Mrs. Patricia Ward Thomas and I have both said that Colonel Stephens never struck the spy. Can you not admit that your point "of crucial importance” is now answered?' (Williams to Rooper, September 25, 1980, WAC, R78/1233/1.)

${ }^{50}$ Rooper to Williams, October 14, 1980, WAC, R78/1233/1.

${ }^{51}$ Shanks to Trethowan, November 6, 1980, WAC, R78/1233/1.

${ }^{52}$ Wilkinson to Shanks, November 25, 1980, WAC, R78/1233/1.

${ }^{53}$ Rooper to Williams, November 24, 1980, WAC, R78/1233/1. 
${ }^{54}$ Shanks to Trethowan, December 3, 1980; Wilkinson to Shanks, December 22, 1980, WAC, $\mathrm{R} 78 / 1233 / 1$.

${ }^{55}$ Shanks to Trethowan, January 4, 1981, WAC, R78/1233/1.

${ }^{56}$ Clegg to Lady Pike, July 9, 1981, WAC, R78/1233/1.

${ }^{57}$ Marks to Clegg, July 10 1981, WAC, R78/1233/1.

${ }^{58}$ Barlow to Clegg, July 23, 1981, WAC, R78/1233/1.

${ }^{59}$ Beith to Trethowan, August 6, 1981, WAC, R78/1233/1.

${ }^{60}$ Clegg to Lady Pike (undated), WAC, R78/1233/1.

${ }^{61}$ Shanks to Trethowan, September 5, 1981, WAC, R78/1233/1.

${ }^{62}$ Rooper to The Secretary, September 17, 1981, WAC, R78/1233/1.

${ }^{63}$ Barlow to Shanks, October 5, 1981, WAC, R78/1233/1.

${ }^{64}$ Warren to Howard, November 25, 1981, WAC, R78/1233/1. It is unclear from the file material whether a reply was ever sent.

${ }^{65}$ Minute, NRL to HS, October 14, 1981, WAC, R78/1233/1.

${ }^{66}$ West, MI5, 187.

${ }^{67}$ Hoare (ed.), Camp 020, 162.

${ }^{68}$ Hoare (ed.), Camp 020, 6.

${ }^{69}$ Kilborn, ““Drama over Lockerbie”’, 59.

${ }^{70}$ Alan and William Shanks to The Editor, Radio Times, February 16, 1980, WAC, $\mathrm{R} 78 / 1233 / 1$.

${ }^{71}$ Shanks to Trethowan, September 24, 1980, WAC, R78/1233/1.

${ }^{72}$ Kilborn, “"Drama over Lockerbie”, 70.

${ }^{73}$ Kilborn, “"Drama over Lockerbie”’, 70, citing Adams et al., ‘The Power of The Right Stuff, 331.

${ }^{74}$ Adams et al., 'The Power of The Right Stuff', 330. 
${ }^{75}$ Adams et al., 'The Power of The Right Stuff', 335.

${ }^{76}$ The 'five techniques' consisted of wall standing, hooding, subjection to noise, deprivation of sleep and deprivation of food and drink.

${ }^{77}$ Newbery, 'Intelligence’, 104.

${ }^{78}$ Conyers, 'Closed-Circuit TV’, March 17, 1979, 8.

${ }^{79}$ Trethowan to Beith, June 19, 1980, WAC, R78/1233/1,

${ }^{80}$ Theobald to Harrop, February 15, 1980, The National Archives (hereafter TNA), CAB $103 / 743$

${ }^{81}$ While the earliest reference to radio or TV programmes in this context cannot be stated definitively, a further early reference can be seen in 1977, during discussion of the possible announcement and publication of the first volume of British Intelligence in the Second World War. In a background note on the subject for the Chair of the JIC, the Intelligence Coordinator, Joe Hooper observed: 'Possible publication should, I think, be considered in relation to the climate of the day. Without doubt there is, at present, considerable public interest in the intelligence and intelligence-related aspects of World War II. This has most recently been brought about by the publication of such books as Winterbotham's 'The Ultra Secret', the television series 'The Secret War' in which Professor R V Jones (whose book is due to be published later this year) played a leading role, and also a series of radio broadcasts by Peter Calvocoressi. There are also a number of other books on intelligence in World War II which are to be published in the near future’. (Hooper to Sykes, February 23, 1977, TNA, CAB 163/256.

${ }^{82}$ Theobald to Harrop, February 7, 1980, TNA, CAB 103/742.

${ }^{83}$ D.J. Wright to Sir Robert Armstrong, March 26, 1980, TNA, CAB 103/742.

${ }^{84}$ Sir Robert Armstrong to Prime Minister, April 3, 1980, TNA, CAB 103/743.

${ }^{85}$ PPS to Armstrong, June 4, 1980, TNA, CAB 103/743. 
${ }^{86}$ Armstrong to Smith, June 16, 1980, TNA, CAB 103/743.

${ }^{87}$ Timewatch: The Spies Who Fooled Hitler.

${ }^{88}$ Ferris, 'The Road to Bletchley Park', 53. 